\title{
18. THE CONCENTRATION AND ISOTOPE COMPOSITION OF SULFUR FROM THE GALAPAGOS MOUNDS AREA SEDIMENTS, LEG 70, DEEP SEA DRILLING PROJECT1
}

\author{
A. A. Migdisov, V. M. Belyi, N. V. Barskaja, and V. A. Grinenko, V. I. Vernadsky Institute of Geochemistry and \\ Analytical Chemistry, USSR Academy of Sciences, Moscow 117334, USSR
}

\section{INTRODUCTION}

Data obtained while investigating the mounds area near the Galapagos Spreading Center demonstrate the direct influence of solutions derived from the interaction of seawater and young oceanic crust on the sedimentary cover. Investigation of metalliferous sediments from the mid-oceanic ridges, the Galapagos mounds, and the FAMOUS-area zone formations have shown that this influence and the resulting products are dependent on composition, temperature, and conditions of solution input.

The study of sulfur in upwardly migrating solutions and the interaction of these solutions with sediments is of great interest. Investigations of different types of hydrothermally derived formations (Edmond, et al., 1979; Spiess et al., 1980; Styrt et al., 1981; Rosanova 1976; Grinenko et al., 1978) have shown the significant role of sulfur-bearing minerals in deposits formed from hightemperature solutions. In contrast, the addition of hydrothermal sulfur is negligible in those metalliferous sediments that precipitated as a result of the interaction between the solutions and open seawater (Bonatti et al., 1972, 1976; Gordeev et al., 1979; Migdisov, Bogdanov, et al., 1979). For example, sulfides are absent in clearly oxidized metalliferous sediments from the East Pacific Rise (EPR). Barite sulfur from these sediments is identical with seawater sulfate sulfur in isotope composition (Grinenko et al., 1978). Gurvich and Bogdanov (1977) have suggested that barium from EPR metalliferous sediments results completely from biological activity and from the components of ocean waters.

Edmond et al. (1979) report that low-temperature springs from the Galapagos Rift axis contain two types of solutions: those with and those without $\mathrm{H}_{2} \mathrm{~S}$.

Cores obtained during Leg 70 of the Deep Sea Drilling Project (DSDP) present useful material for studying the role of sulfur in the formation of mounds, which are assumed to result from the interaction of hydrothermal solutions with sediments. These cores contain sedimentary sequences from mounds and off-mounds that are almost undisturbed by drilling. Sediments from low heatflow areas, which lacked the influence of hydrothermal solutions, were also sampled in detail. This permitted us to compare sulfur concentration and sulfur-isotope com-

\footnotetext{
${ }^{1}$ Honnorez, J., Von Herzen, R. P., et al., Init. Repts. DSDP, 70: Washington (U.S. Govt. Printing Office).
}

position in sediments and pore waters from both low heat-flow areas and the mounds region. The occurrence of worm burrow tubes of pyrite (Fig. 1) in the lower mounds sediments (compare hydrothermal smectites in burrows within the lower mounds pelagic oozes) also provided a reason for searching for hydrothermal sulfur in the mounds sections.

\section{ANALYTICAL PROCEDURE}

The separation of sulfur from sediments and determination of pyrite and monosulfide were performed using the method suggested by Volkov and Zhabina (1977), with a determination limit of $0.001 \%$.

Separation of sulfate from pore waters as $\mathrm{BaSO}_{4}$ was carried out, the error being less than $0.01 \%( \pm 0.006 \%$ from the data of parallel, duplicate analyses). Isotopic analysis of $\mathrm{SO}_{2}$ was performed by means of the MI-1305 mass spectrometer, following the procedure suggested by Ustinov and Grinenko (1965); the experimental error was $0.3 \%$. $\delta^{34} \mathrm{~S}$ data were expressed as parts per mil relative to the meteorite standard.

\section{RESULTS}

The data obtained on pyrite sulfur in sediments and sulfate sulfur in pore waters, as well as on the isotope composition of the sulfur, are shown in Tables 1 to 4 and Figures 2 to 5 . In plotting the graphs, we also used the results of $\mathrm{C}_{\text {org }}$ determinations performed on board the Glomar Challenger.

\section{Sulfide and Sulfur Sediments}

The content of sulfide sulfur was determined in $\mathbf{5 6}$ samples from 11 hole sections. Monosulfide occurs in amounts below the limits of determination. The contents of pyrite sulfur varied significantly in analyzed samples.

In green clays from the hydrothermal mounds, the content of pyrite sulfur was very low. In nine samples, which occurred mainly as pure granulated smectite, these clays were too poor in sulfur $(<0.001 \%)$. In weight samples (mainly fine grained and mixed with pelagic-ooze smectites) the amounts of pyrite sulfur in smectite varied from $0.005 \%$ to $0.039 \%$, with an average of $0.019 \%$. Averaging all determinations from 17 samples of green clays yields a pyrite-sulfur content of $0.009 \%$.

Upper pelagic sediments from the mounds sections were practically lacking in pyrite sulfur $(<0.001 \%)$. Alternating with smectite, pelagic oozes from hydrothermal units varied in pyrite-sulfur concentration by three orders of magnitude $(<0.001 \%-0.156 \%)$, the average being $0.200 \%$. Great variation was also observed in pyrite-sulfur concentrations in the lower pelagic sediments 

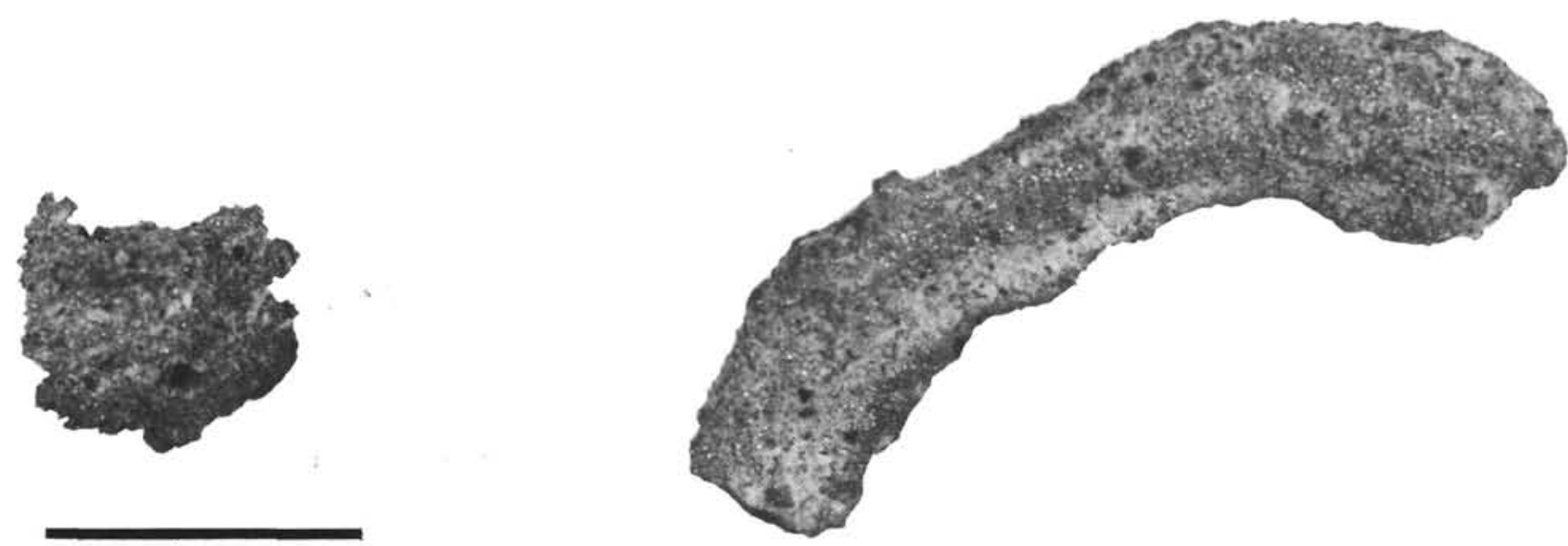

$1 \mathrm{~cm}$

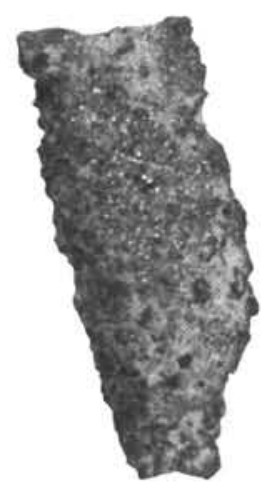

Figure 1. Pyrite worm tubes from the lower pelagic sediments, Hole 506C.

of the mounds $(0.103 \%-1.196 \%)$. In these layers occurs the maximum concentration of $\mathrm{S}_{\mathrm{pyr}}$, and this is also where sulfide worm tubes were found, which measured up to $5 \mathrm{~cm}$ in length (Fig. 1).

The highest dispersed pyrite concentrations were localized in some burrows. The parts of the burrows with high pyrite concentrations were also enriched by a brown opaque material assumed to be organic carbon.

Off-mounds sediments (Holes 507C, 507H, and 509) were characterized by lower amounts of pyrite-sulfur content with wide fluctuations $(0.011 \%-0.389 \%)$. Minimum concentrations in off-mounds sections were found in the deepest sediments. In other parts of the sections, pyrite distribution is more homogeneous $(0.101 \%$ $0.389 \%$ ). All but the deepest low heat-flow area sediments (Holes 508 and 510) revealed rather small $\mathrm{S}_{\mathrm{pyr}}$ content variations $(0.079 \%-0.135 \%$ and $0.109-0.422 \%$ for Holes 508 and 510, respectively). Some depletion in pyrite in the upper oxidized layer $\left(\mathrm{S}_{\mathrm{pyr}}=0.049 \%\right)$ should also be mentioned. The basal horizon of Hole 508, which belongs to a lithified layer of partly recrystallized foraminiferous sediment, was practically lacking in $\mathrm{S}_{\mathrm{pyr}}$. Low concentrations of $\mathrm{S}_{\mathrm{pyr}}$ in basal sediment of other holes from that site (e.g., Hole 508C) have been confirmed as a regular characteristic in this region.

The isotope composition of pyrite sulfur in analyzed samples is fairly homogeneous and characterized by a high accumulation of light-sulfur isotopes $\left(\delta^{34} \mathrm{~S}=\right.$
$-40 \%$ ). Only three exceptions can be noted. In one sample, from an alternating layer of smectite pelagic ooze, slightly lower ${ }^{32} \mathrm{~S}$ accumulation is observed $\left(\delta^{34} \mathrm{~S}=\right.$ $-37.6 \%$ ). The same situation is peculiar to samples from the deep horizons of Hole $508\left(\delta^{34} \mathrm{~S}=-35.8\right.$ to $-32.9 \%$ ).

\section{Sulfate Sulfur of Pore Waters}

Sulfate concentrations in pore waters from moundsarea sediments vary within narrow limits which are close to the values in seawater $(0.086 \%-0.112 \%)$. In different types of mounds sediments, the average contents of sulfate sulfur are practically identical $(0.093 \%-0.095 \%)$. The average sulfate-sulfur concentration of pore waters from off-mounds sediments is very close to these values $(0.100 \%)$.

The isotopic composition of sulfate sulfur from pore waters from the mounds formation also varied slightly $\left(\delta^{34} \mathrm{~S}=18.2-20.6 \%\right)$. The average isotope composition of sulfate sulfur from different types of mounds sediments was similar and close to that of seawater $\left(\delta^{34} \mathrm{~S}=\right.$ $19.2-19.8 \%$ ). In sediments from low heat-flow areas, occurrences of $\mathrm{H}_{2} \mathrm{~S}$ were observed in both Hole 508 (with $35 \mathrm{~m}$ of sediments) and, especially, Hole 510 (with $110 \mathrm{~m}$ of sediment cover). In pore waters from both holes, high $\mathrm{NH}_{3}$ content was detected as a result of microbiological sulfate reduction; in pore waters from Hole 510 high concentrations of $\mathrm{H}_{2} \mathrm{~S}$ (up to $360 \mathrm{~m}$ ) were 
Table 1. Concentration and isotope composition of sulfur in sediments, Site 506.

\begin{tabular}{|c|c|c|}
\hline \multirow{2}{*}{$\begin{array}{c}\text { Sample } \\
\text { (interval in } \mathrm{cm} \text { ) }\end{array}$} & \multicolumn{2}{|c|}{ Pyrite Sulfur } \\
\hline & (wt.\%) & $\delta^{34} \mathrm{~S}(\%)$ \\
\hline \multicolumn{3}{|l|}{ Hole 506} \\
\hline $\begin{array}{l}1-1,45-47 \\
2-1,56-60 \\
3-1,52-54 \\
3-2,143-146 \\
4-3,123-126 \\
6-1,46-48 \\
6-2,62-65 \\
6-3,47-49 \\
7-3,53-57 \\
8-1,3-5 \\
8-1,98-100\end{array}$ & $\begin{array}{r}<0.001 \\
<0.001 \\
<0.001 \\
<0.001 \\
<0.001 \\
0.008 \\
0.005 \\
0.122 \\
0.561 \\
0.001 \\
0.030\end{array}$ & $\begin{array}{l}\text { n.d. } \\
\text { n.d. } \\
\text { n.d. } \\
\text { n.d. } \\
\text { n.d. } \\
\text { n.d. } \\
\text { n.d. } \\
-46.6 \\
-37.6 \\
\text { n.d. } \\
-46.3\end{array}$ \\
\hline \multicolumn{3}{|l|}{ Hole $506 \mathrm{C}$} \\
\hline $\begin{array}{l}2-2,42-44 \\
3-1,33-39 \\
6-2,107-109 \\
6-2,113-115 \\
6-2 \text { pyrite } \\
\text { worm tube } \\
6-3,64-69 \\
8-1,91-93 \\
8-1,102-104 \\
8 C C \text { pyrite } \\
\text { worm tube }\end{array}$ & $\begin{array}{l}0.018 \\
0.039 \\
0.181 \\
0.296\end{array}$ & $\begin{array}{l}\text { n.d. } \\
\text { n.d. } \\
-42.6 \\
-44.8 \\
\\
-43.0 \\
-43.7 \\
\text { n.d. } \\
\text { n.d. } \\
-42.5\end{array}$ \\
\hline \multicolumn{3}{|l|}{ Hole 506D } \\
\hline $\begin{array}{l}1-1,99-103 \\
2-1,81-85 \\
3-2,54-57 \\
6-1,39-45 \\
8-1,98-105\end{array}$ & $\begin{array}{l}0.036 \\
0.207 \\
0.103 \\
1.196 \\
0.142\end{array}$ & $\begin{array}{l}-41.2 \\
-48.3 \\
-46.2 \\
-43.4 \\
-45.5\end{array}$ \\
\hline
\end{tabular}

Note: $\mathrm{n}, \mathrm{d} . \mathrm{=}$ not determined .

also determined (Bender, this volume). Sulfate sulfur concentrations in pore waters from these sediments reflect less variation than can be expected as a result of active sulfate reduction. In Hole 508, sulfate-sulfur concentration was $0.088 \%$ to $0.098 \%$, and $\delta^{34} \mathrm{~S}$ was 18.1 to $20.00 \%$. Limits of sulfur-content variation in Hole 510 waters are $0.079 \%$ to $0.090 \%$, and $\delta^{34} \mathrm{~S}$ values of this sulfate varied from 21.5 to $25.4 \%$. The occurrences of hydrogen sulfide in the pore waters suggest that sulfide may be partly oxidized into sulfate either in sediments or during pore-water sampling and analysis.

\section{DISCUSSION}

The data presented here suggest that the pure hydrothermal smectites are practically lacking in reduced sulfur. There is a tendency for sulfide to increase with depth, which correlates roughly with an increase in reduced iron content in smectites. Low $\mathrm{S}_{\text {pyr }}$ content in the green clays is clearly related to transition of the pure granulated smectites to fine-grained smectites mixed with pelagic oozes. For this reason, the admixture of pelagic sediment is thought to be responsible for the conservation of sulfide sulfur from parent pelagic oozes
Table 2. Concentration and isotope composition of sulfur in sediments and pore water, Site 507.

\begin{tabular}{|c|c|c|c|c|c|}
\hline \multirow{2}{*}{$\begin{array}{c}\text { Sample } \\
\text { (interval in } \mathrm{cm} \text { ) }\end{array}$} & \multicolumn{2}{|c|}{ Pyrite Sulfur } & \multicolumn{2}{|c|}{$\begin{array}{l}\text { Sulfate of } \\
\text { Pore-Water }\end{array}$} & \multirow{2}{*}{$\frac{\text { Sulfur }}{\delta^{34} \mathrm{~S}(\%)}$} \\
\hline & (wt.\%) & $\delta^{34} \mathrm{~S}\left(\%_{0}\right)$ & (no.) & $\overline{\text { (wt. \%) }}$ & \\
\hline \multicolumn{6}{|l|}{ Hole $507 \mathrm{C}$} \\
\hline $1-3,121-125$ & 0.165 & -41.8 & & & \\
\hline \multicolumn{6}{|l|}{ Hole 507D } \\
\hline $\begin{array}{l}3-3,59-63 \\
3-3,78-89 \\
4-1, \\
5-1,75-80 \\
5-3, \\
6-3,117-121 \\
8-3,56-60 \\
8-3, \\
9-3,8-10 \\
9-3,100-110 \\
10-1,12-14\end{array}$ & $\begin{array}{r}<0.001 \\
0.029 \\
0.182 \\
0.121 \\
\\
0.017\end{array}$ & $\begin{array}{l}\text { n.d. } \\
\text { n.d. } \\
-45.2 \\
-48.9 \\
-45.2 \\
\text { n.d. }\end{array}$ & $\begin{array}{l}64 \\
65 \\
69\end{array}$ & $\begin{array}{l}0.089 \\
0.092 \\
0.096\end{array}$ & $\begin{array}{l}\text { n.d. } \\
20.6 \\
\\
18.2\end{array}$ \\
\hline \multicolumn{6}{|l|}{ Hole 507F } \\
\hline $\begin{array}{l}1-1,89-91 \\
1-1,140-150 \\
3-1,54-58 \\
4-2,56-60 \\
4-3 \\
7-1,139-150\end{array}$ & $\begin{array}{r}<0.001 \\
\\
0.298 \\
0.365\end{array}$ & $\begin{array}{l}\text { n.d. } \\
-50.6 \\
-46.4\end{array}$ & $\begin{array}{l}82 \\
87\end{array}$ & $\begin{array}{l}0.090 \\
0.097\end{array}$ & $\begin{array}{l}18.6 \\
19.7\end{array}$ \\
\hline \multicolumn{6}{|l|}{ Hole $507 \mathrm{H}$} \\
\hline $\begin{array}{l}6-1,53-55 \\
8-1,115-119\end{array}$ & $\begin{array}{l}0.101 \\
0.011\end{array}$ & $\begin{array}{l}-45.1 \\
\text { n.d. }\end{array}$ & & & \\
\hline
\end{tabular}

Note: n.d. $=$ not determined.

Table 3. Concentration and isotope composition of sulfur in sediments and pore water, Site 509.

\begin{tabular}{|c|c|c|c|c|c|}
\hline \multirow{2}{*}{$\begin{array}{c}\text { Sample } \\
\text { (interval in } \mathrm{cm} \text { ) }\end{array}$} & \multicolumn{2}{|c|}{ Pyrite Sulfur } & \multicolumn{3}{|c|}{$\begin{array}{l}\text { Sulfate of Pore-Water } \\
\text { Sulfur }\end{array}$} \\
\hline & (wt.\%) & $\delta^{34} \mathrm{~S}(\%)$ & (no.) & (wt.\%) & $\delta^{34} \mathrm{~S}(\%)$ \\
\hline \multicolumn{6}{|l|}{ Hole 509B } \\
\hline $\begin{array}{l}1-1,150 \\
3-1,150 \\
3-2,50 \\
3-2,68-72 \\
4-2,7-12 \\
5-1,18-20 \\
6-2,28-30 \\
7-3,70-74\end{array}$ & $\begin{array}{r}<0.001 \\
<0.001 \\
0.454 \\
0.115 \\
0.164\end{array}$ & $\begin{array}{l}\text { n.d. } \\
\text { n.d. } \\
-48.1 \\
-48.1 \\
-45.4\end{array}$ & $\begin{array}{l}118 \\
119 \\
120\end{array}$ & $\begin{array}{l}0.086 \\
0.095 \\
0.103\end{array}$ & $\begin{array}{l}18.6 \\
20.5 \\
19.5\end{array}$ \\
\hline \multicolumn{6}{|l|}{ Hole 509} \\
\hline $\begin{array}{l}2-3,139-150 \\
3-3,50-52 \\
3-3,130-140 \\
4-3,110-125 \\
4-3,80-82 \\
6-2,91-95 \\
6-2,140-150 \\
8-1,19-21 \\
8-1,139-150\end{array}$ & $\begin{array}{l}0.359 \\
0.273\end{array}$ & $\begin{array}{l}-49.3 \\
-48.1 \\
-45.3\end{array}$ & $\begin{array}{l}124 \\
127 \\
130\end{array}$ & $\begin{array}{l}0.111 \\
0.092 \\
0.097\end{array}$ & $\begin{array}{l}19.0 \\
18.3 \\
19.2\end{array}$ \\
\hline
\end{tabular}

Note: n.d. $=$ not determined . 
Table 4. Concentration and isotope composition of sulfur in sediments and pore water, Holes 508 and 510.

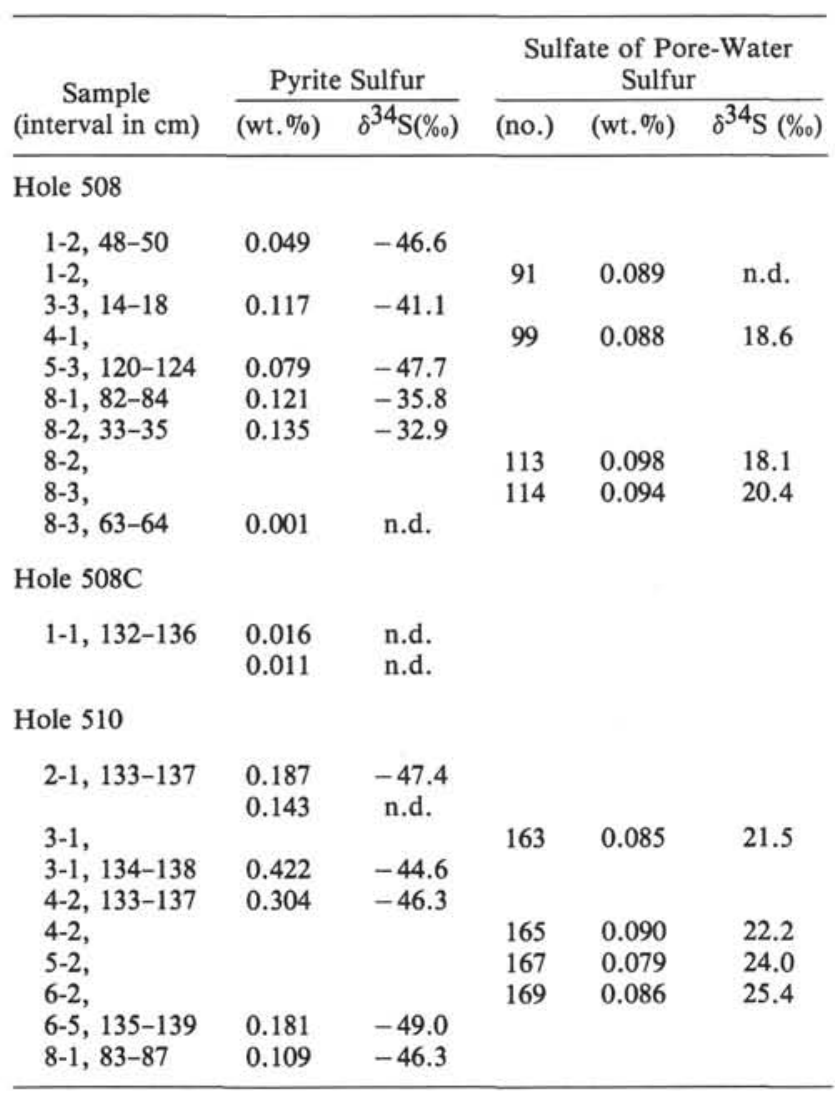

Note: n.d. $=$ not determined.

in hydrothermal sediments. This hypothesis is confirmed by the isotope composition of pyrite sulfur from the hydrothermal smectite (Sample 507D-6-3, 117-121 $\mathrm{cm})$. The value obtained $\left(\delta^{34} \mathrm{~S}=-45.2 \%\right.$ ) is considered identical to those from the mounds and off-mounds pelagic oozes $\left(\delta^{34} \mathrm{~S}=-40\right.$ to $\left.-51 \%\right)$, which are characterized by extremely high accumulations of the light-sulfur isotope.

The isotope compositions of sulfide sulfur from the low heat-flow area $\left(\mathrm{o}^{34} \mathrm{~S}=-41\right.$ to $-49 \%$ ) are similar to those from the mounds regions. It must be stressed that accumulation of light sulfur $\left.{ }^{32} \mathrm{~S}\right)$ in sulfides is also observed in the deepest sediments investigated (up to $110 \mathrm{~m}$ sub-bottom depth in Hole 510). This peculiarity in the isotope composition of sulfide sulfur is assumed to be common in pelagic sediments in the area investigated. This is confirmed by the results of previous investigations (Migdisov et al., 1978) of the upper 4-meterthick sediment layer of the SE Pacific $\left(3^{\circ} \mathrm{S}-4^{\circ} \mathrm{N} ; 86^{\circ} \mathrm{W}-\right.$ $101^{\circ} \mathrm{W}$ ), including the area under discussion (Figs. 6 $\mathrm{A}, \mathrm{B})$. The values of $\delta^{34} \mathrm{~S}$ of pyrite dispersed in the sediments are very homogeneous and characterized by high ${ }^{32} \mathrm{~S}$ accumulation. The average values of $\delta^{34} \mathrm{~S}$ and $\mathrm{S}_{\mathrm{pyr}}$ concentrations are considered to be background levels for pyrite sulfur concentrations and isotope compositions in sediments of this whole area. One should note the close similarities between data obtained for the mounds and low heat-flow areas and background val- ues. All the data presented support the thesis (Migdisov, Girin, et al., 1979) that high accumulation of ${ }^{32} \mathrm{~S}$ in sulfides during the process of sulfate reduction (providing the process is taking place) is obtained in pelagic sediments at deep water depths and rather slow rates of accumulation of sediments. The common occurrence of the peculiarity is emphasized by Goldhaber and Kaplan's (1974) data on $\delta^{34} \mathrm{~S}$ values of pyrite sulfur from pelagic sediments in the Pacific $\left(\delta^{34} \mathrm{~S}\right.$ up to $-48 \%$ ) and the results of our investigation (Migdisov, Girin, et al., 1979) of pelagic sediments from the Indian Ocean $\left(\delta^{34} \mathrm{~S}=-46\right.$ to $\left.-48 \%\right)$.

It is known (Kaplan and Rittenberg, 1964; Goldhaber and Kaplan, 1974) that accumulation of the light sulfur isotope results from the process of bacterial sulfate reduction, which is controlled by the rate of $\mathrm{S}^{-2}$ generation by cell. In turn, the rate of $\mathrm{S}^{-2}$ generation depends on sulfate concentration in the water, organic carbon content, and other nutrients present in the bacteria's environment.

For the sediments under discussion, the $\mathrm{C}_{\text {org }}$ content is found to be, on average, 0.4 to $0.6 \%$. Similar concentrations are characteristic of the whole area's upper layer of sedimentary cover (Migdisov et al., 1978). Only the more deeply buried sediments from Hole 510 differ in elevated amounts of organic carbon (average $\mathrm{C}_{\text {org }}=$ $1.0 \%$ ). Hence, all but Hole 510 sediments are assumed to contain moderate amounts of organic carbon. Most likely the high rate of sulfide generation cannot be provided by these concentrations.

Sulfate content in pore waters from the upper sediments and its sulfur-isotope composition is observed (Migdisov et ai., 1978) to be similar to that of seawater $\left(\mathrm{S}_{\mathrm{SO}_{4}}{ }^{2-}=0.094 \%-0.104 \% ; \delta^{34} \mathrm{~S}=+19.2 \%-+21.0 \%\right)$. The data for pore waters from high heat-flow areas are close to the values $\left(\mathrm{S}_{\mathrm{SO}_{4}}{ }^{2-}=0.092 \%-0.112 \% ; \delta^{34} \mathrm{~S}=\right.$ $+18.3 \%-+19.7 \%$ ). Pore-water analysis (see Bender, this volume) showed that sulfate reduction occurs only in the upper horizons of the sediments not depleted in sulfate. The stability of the sulfate concentrations in pore water also suggested that the process of bacterial sulfate-reduction is restricted by the upper horizons of the sedimentary layer. These conditions are in accordance with a high accumulation of ${ }^{32} \mathrm{~S}$ in sulfides.

In sediments from Holes 508, where direct evidences of $\mathrm{H}_{2} \mathrm{~S}$ generation at depth of the sedimentary sections were obtained, this process affects only slightly both sulfide formation and the isotope composition of sulfide sulfur. For example, in sediments from Hole 510, where the generation of $\mathrm{H}_{2} \mathrm{~S}$ was found to be maximum, the sulfide is characterized by the same isotope composition as in the upper layers of pelagic sediments. Bacterial reduction of sulfate in a closed or partly closed system (Goldhaber and Kaplan, 1974) results in a decrease in the sulfate-sulfur content and in accumulation of the heavy-sulfur isotope. In fact, we observed the peculiarities for Hole 510 pore waters $\left(\delta^{34} \mathrm{~S}\right.$ up to $+25.4 \%$ ). But if the process occurs in a closed system, isotopically heavier sulfides (compared with the upper horizons) will be formed. The absence of isotopically heavy sulfide sulfur in the deep layers of the hole section is probably 


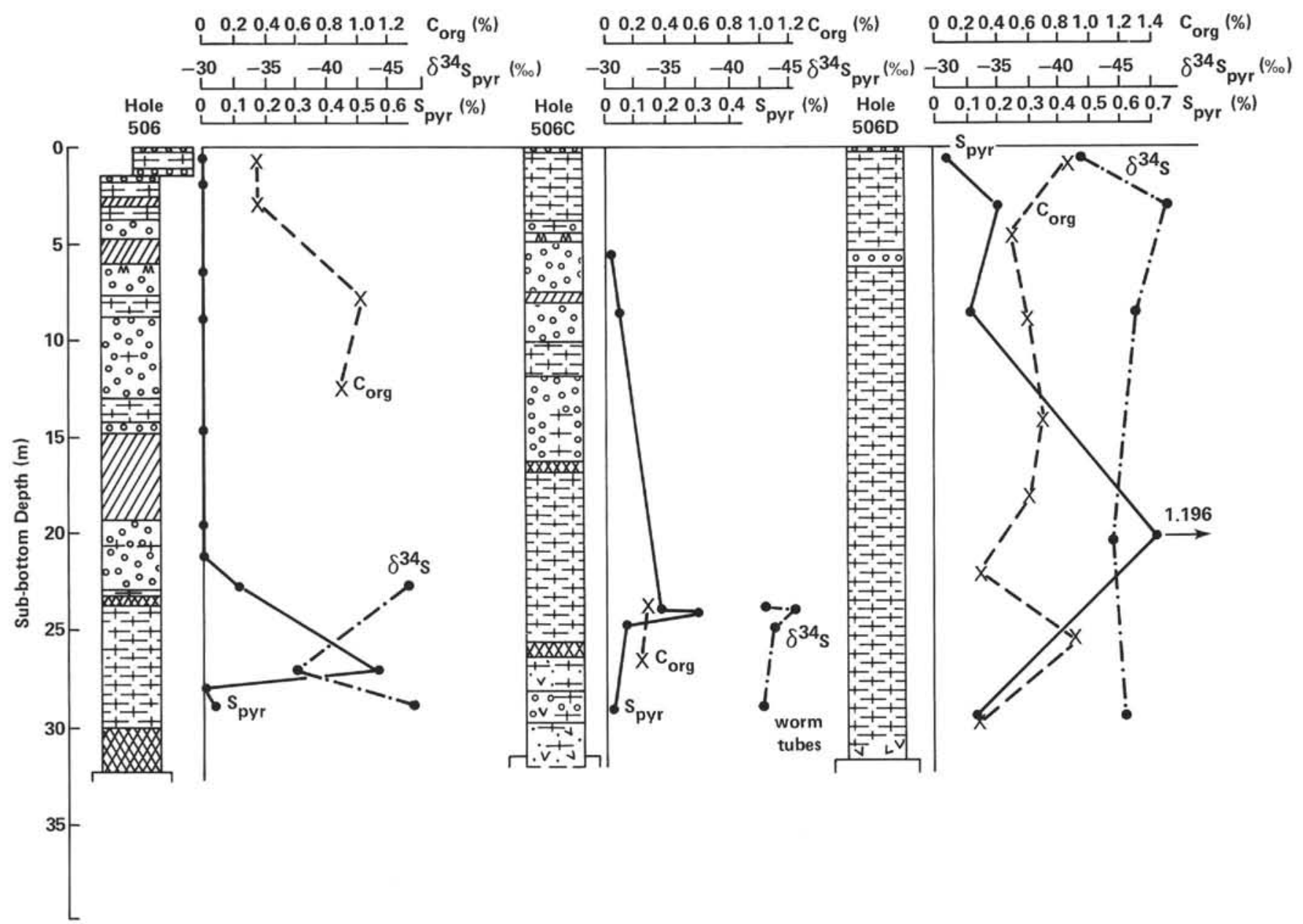

Figure 2. Concentrations of pyrite sulfur and organic carbon, plus $\delta^{34} \mathrm{~S}$ of pyrite sulfur, in sediments from Site 506.

related to a slight degree of sulfide pyritization. It has been mentioned repeatedly that the intensity of the process is limited by the ferrous iron content in sediments (Berner, 1964; Volkov, 1961; Strakhov, 1960; Goldhaber and Kaplan, 1974). It is probable that as a result of a low content of ferrous iron in sediments $(\mathrm{FeO}=$ $0.5 \%-0.6 \%$ in Hole 510 sediments and $0.4-1.6 \%$ in oozes from Hole 508) the $\mathrm{H}_{2} \mathrm{~S}$ generated within the depth of sedimentary layer has not had opportunity to form significant amounts of pyrite and too slight additions of newly formed pyrite are observed.

The only observation of fixation of isotopically heavy sulfide sulfur is in the lowest part of the sedimentary section of Hole 508. This contradicts the evidence on lower-sediment sulfate reduction compared with Hole 510 sediments, with decreasing $\mathrm{NH}_{3}$ in pore waters with depth (Bender, this volume), and with the absence of any enrichment of pore-water sulfate in heavy-sulfur isotopes. It is thought that this lower-sediment sulfide enrichment is not related to common sulfate reduction processes in a closed system. In fact, the lower horizon of the section from Hole 508 is a layer of recrystallized, lithified carbonate lacking in siliceous tests. Well-crystallized but sparse crystals of pyrite were observed here, in contrast to the common framboidal form of pyrite in other horizons of pelagic sediments. In analytical deter- minations of pyrite sulfur, only traces or negligible amounts were observed. Dissolution, subtraction, and partial recrystallization of pyrite in the lowest layers of Hole 508 are thought to be associated with silica output and lithification of carbonate ooze (see Hole 508 core description) in this horizon. Mobilization of ferrous iron in this process (including dissolved pyrite), with the addition of generated and isotopically heavier $\mathrm{H}_{2} \mathrm{~S}$, are seen to lead to formation of pyrite with a higher content of $\delta^{34} \mathrm{~S}$ above the partially lithified layer.

In general, it can be concluded that sulfide-sulfur minerals form mainly in the upper horizons of sediments in the area investigated. It is probable that a sufficient content of sulfate and limited concentration of organic carbon in sediments (and perhaps great ocean depths) led to a small rate of $\mathrm{S}^{2-}$ generation, and results in high ${ }^{32} \mathrm{~S}$ accumulation in pelagic oozes.

Examples of highly dispersed sulfide-sulfur content $(>1 \%)$ and even occurrences of pyrite concentration in mounds-area pelagic sediments are not common. Their occurrence suggests bioturbation, implying both the presence of sulfate and a local enrichment of organic carbon. Meanwhile, the sulfur-isotope composition of the concentrated form of pyrite is identical to that dispersed in sediments. This implies that pyrite from the sediments is being incorporated into worm tubes. 


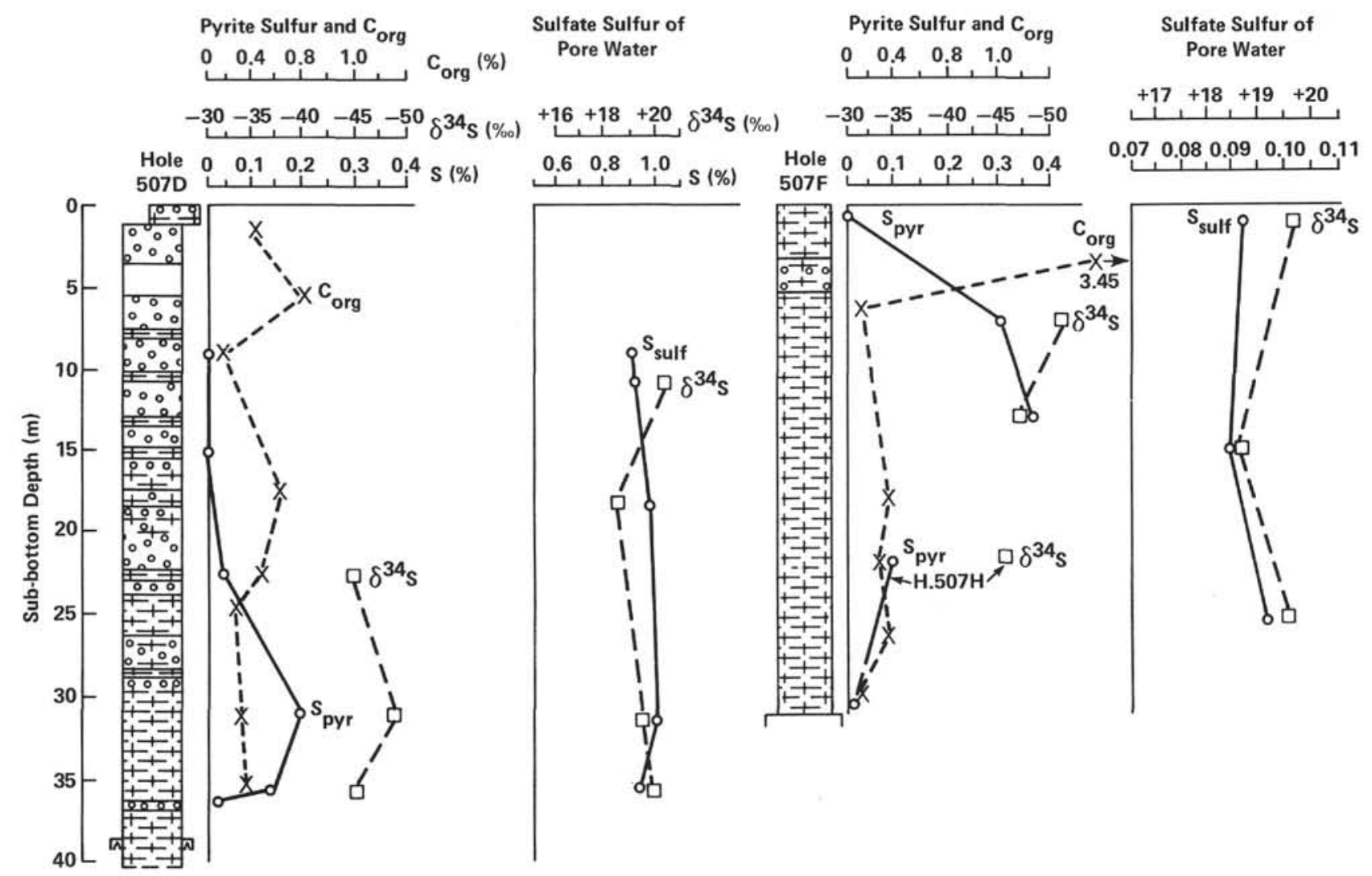

Figure 3. Concentrations of sulfide and sulfate sulfur and organic carbon, plus $\delta^{34} \mathrm{~S}$ of pyrite and sulfate sulfur values, in Site 507 sediments and pore waters.

The most remarkable fluctuation of sulfide-sulfur content observed in mounds pelagic ooze is presumably connected with the influence of hydrothermal solutions. The effect of these solutions percolating upward through the sedimentary cover on siliceous-carbonate oozes resulted in dissolution of silica and carbonate and formation of iron-rich smectites and manganese-oxide crust; the chemical reactions of this process have been proposed by Honnorez et al. (1981). One peculiarity of the process is the oxidized form of iron in the main resulting product-that is, in smectite. Hydrothermal solutions, in a reduced state, must be oxidized by oxygen (or $\mathrm{MnO}_{2}, \mathrm{NH}_{3}$, etc.) during the smectite formation. This suggests that oxidation must occur during the interaction between solutions and sediments and that reduced components in both must be oxidized. Thus, oxidation of organic carbon, and oxidation and dissolution of pyrite should be observed. This leads also to redistribution and inhomogeneity in the distribution of reduced minerals in mound oozes. Traces of pyrite, sometimes occurring in slightly reduced lower smectites (especially in mixed ones) confirm the relationship between pyrite content (or its preservation) and redox conditions in an interacting solution-ooze system.

It is probable that intensive circulation in the mounds will prevent us from tracing the oxidation of sulfides in sediments. Unusually low values of $\delta^{34} \mathrm{~S}$ of sulfate sulfur in mounds pore water $\left(\delta^{34} \mathrm{~S}\right.$ to $\left.18.2 \%\right)$ may reflect this process. Nevertheless, the data suggest that the solu- tions are lacking in hydrothermal sulfur, or that its concentration is very small, assuming that the process of hydrothermal sediment formation is proceeding at the present time.

\section{REFERENCES}

Berner, R. A., 1964. Distribution and diagenesis of sulfur in some sediments from the Gulf of California. Mar. Geol., 1:117-140.

Bonatti, E., Fisher, D., Joensuu, O., et al., 1972. Iron-manganesebarium deposits from the Afar Rift (Ethiopia). Econ. Geol., 67: 717-730.

Bonatti, E., Zerbi, M., Kay, R., et al., 1976. Metalliferous deposits from the Appenine ophiolites: Mesozoic equivalents of modern deposits from oceanic spreading centers. Bull. Geol. Soc. Am., 87: 83-84.

Dymond, J. R., Corliss, J., Heath, G., et al., 1973. Genesis of ironrich sediments from the East Pacific Rise. Bull. Geol. Soc. Am., 84(10):3355-3372.

Edmond, J. M., Measures, C., McDuff, R. E., et al., 1979. Ridge crest hydrothermal activity and the balances of the major and minor elements in the ocean: The Galapagos data. Earth Planet. Sci. Lett., 46:1-19.

Goldhaber, M. B., and Kaplan, I. R., 1974. The sulfur cycle. In Goldberg, E. D. (Ed.), The Sea, (Vol. 5): New York (Wiley), 569-655.

Gordeev, V. V., Demina, L. P., and Konkin, A. I., 1979. Hydrothermally derived $\mathrm{Fe}$ and $\mathrm{Mn}$ in deep waters of Pacific (Galapagos active zone, Hess deep). In Smirnov, V. I. (Ed.), Metalliferous Sediments of the Southeastern Pacific: Moscow (Nauka) pp. 237-248.

Grinenko, V. A., Migdisov, A. A., Girin, Yu. P., et al., 1978. On the sources of sulfur in bedrocks and sediments of active zones of the southeastern part of the Pacific. Proc. 7th Nat. Symp. Stable Isot. Geochem. (Moscow).

Gurvich, E. C., and Bogdanov, Yu. A., 1978. The fate of barium in the recent sedimentation in Pacific. Geochimia, 3:359-374. 
Kaplan, I. R., and Rittenberg, S. C., 1964. Microbiological fractionation of sulfur isotopes. J. Gen. Microbiol., 34:195-212.

Migdisov, A. A., Bogdanov, Ju. A., Lisitsin, A. P., et al., 1979. Geochemistry of metalliferous sediments. In Smirnov, V. I., (Ed.), Metalliferous Sediments of the Southeastern Pacific: Moscow (Nauka) 122-200.

Migdisov, A. A., Girin, Ju. P., Galimov, E. M., et al., 1980. Major and minor elements and sulfur isotopes of the Mesozoic and Cenozoic sediments at Sites 415 and 416, Leg 50, DSDP. In Lancelot, Y., Winterer, E. L., et al., Init. Repts. DSDP, 50: Washington (U.S. Govt. Printing Office), 675-689.

Migdisov, A. A., Girin, Ju. P., and Grinenko, V. A., 1978. Sulfur in sediments of the southeastern part of the Pacific. Proc. 7th Nat. Symp. Stable Isot. Geochemi: (Moscow).

Rosanova, T. V., 1976. On the occurrence of kerolite, pirrotite and troilite in Hess Deep sediments. Litologia i Poleznye Iskopaemye, 2.

Spiess, F. N., MacDonald, K. S., Atwater, T., et al., 1980. East Pacific Rise Hot Springs and Geophysical Experiments. Science, 207: 1421-1433.
Strakhov, N. M., 1960. Principles of Lithogenesis. (Vol. 2): Moscow (Nauka).

Styrt, M. M., Brackmann, A. J., Holland, H. D., et al., 1981. The mineralogy and the isotopic composition of sulfur in hydrothermal sulfide/sulfate deposits on the East Pacific Rise, $21^{\circ} \mathrm{N}$ Latitude. Earth Planet. Sci. Lett., 53:382-390.

Ustinov, V. I., and Grinenko, V. A., 1965. A Precision Mass-Spectrometric Method for the Determination of Sulfur Isotopic Composition: Moscow (Nauka).

Volkov, I. I., 1961. Iron sulfides: Their interdependence and transformations in the Black Sea bottom sediments. Trudy Inst. Oceanol. Ak. Nauk SSSR, 50:68-92.

Volkov I. I., and Zhabina, N. N., 1977. Determination of pyritic sulfur by means of metallic chromium and chromic salt solution (II). In Ostroumov, E. A. (Ed.), Chemical Analysis of Sea Sediments: Moscow (Nauka), pp. 5-14.

Honnorez, J., Von Herzen, R. P., and Shipboard Scientific Party, 1981. Hydrothermal mounds and young ocean crust of the Galapagos: Preliminary. Deep Sea Drilling results, Leg 70. Geol. Soc. Am. Bull., 92(1):457-472.

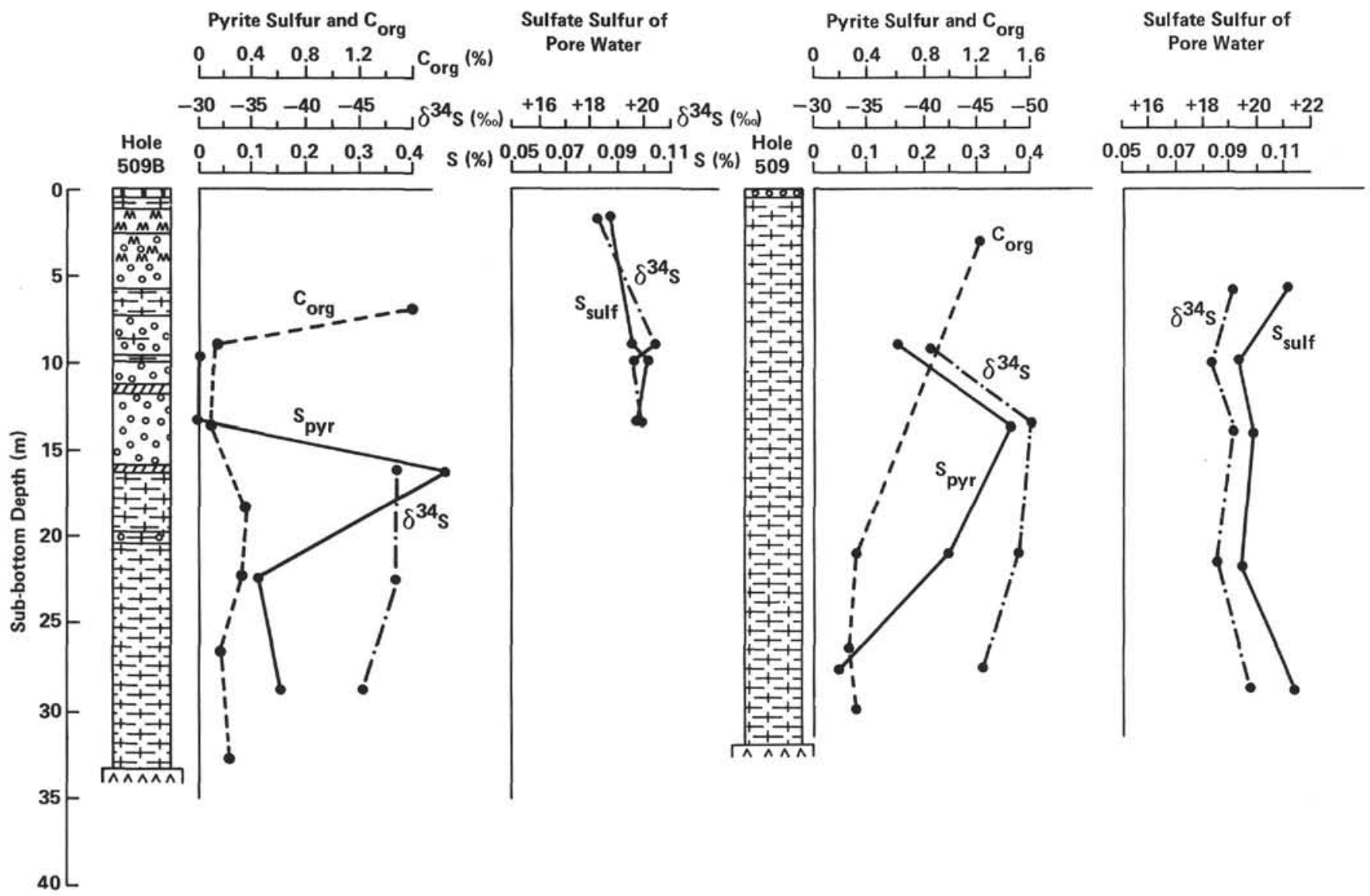

Figure 4. Concentrations of sulfide and sulfate sulfur and organic carbon, plus $\delta^{34} \mathrm{~S}$ of pyrite and sulfate sulfur values, in Site 509 sediments and pore waters. 


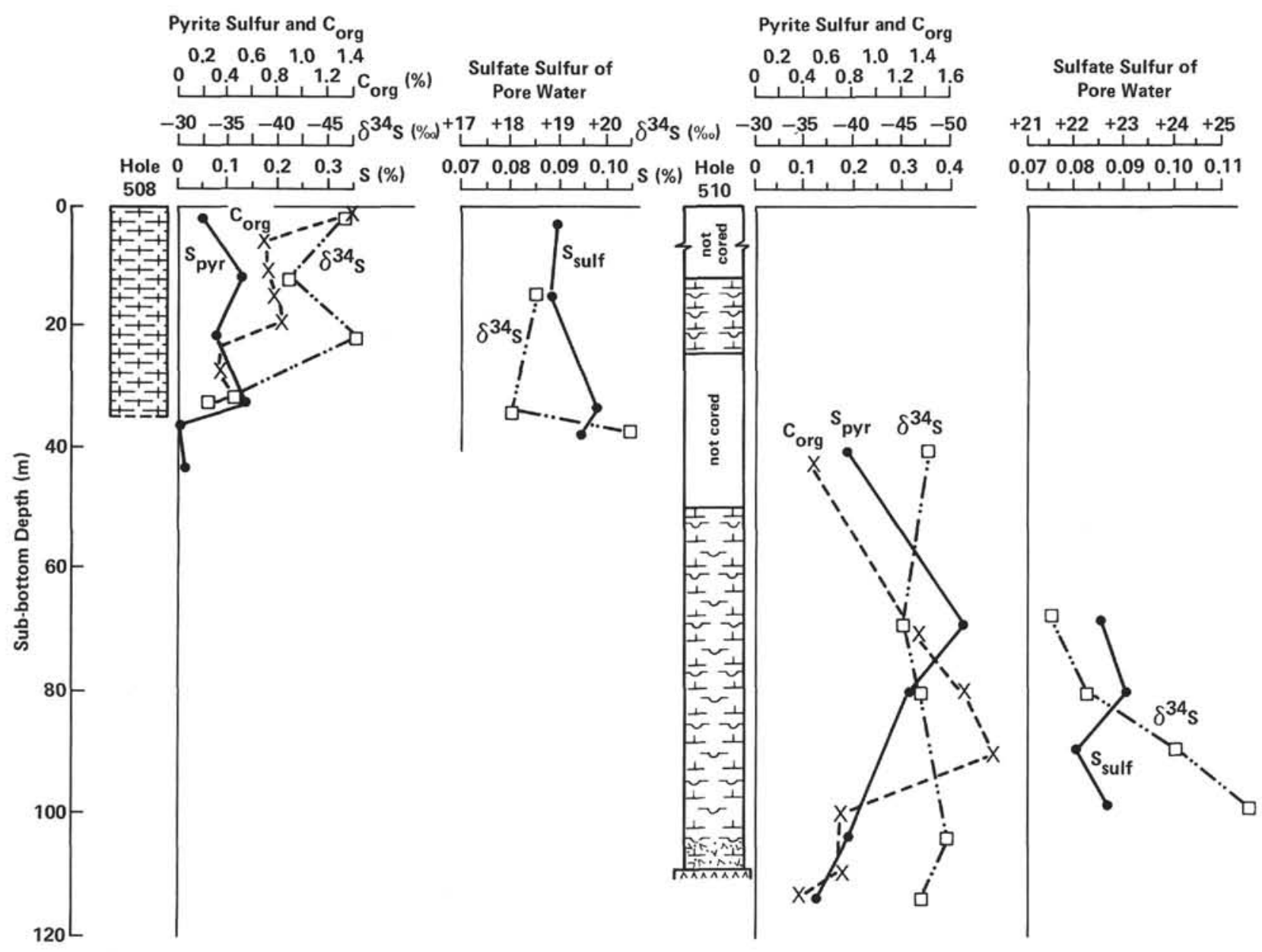

Figure 5. Concentrations of sulfide and sulfate sulfur and organic carbon, plus $\delta^{34} \mathrm{~S}$ of pyrite and sulfate sulfur values, in Holes 508 and 510 sediments and pore waters. 


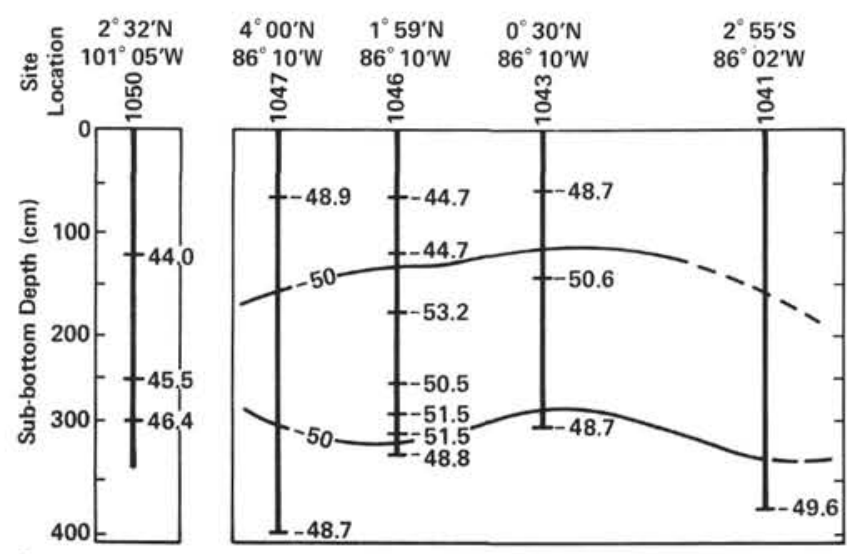

A

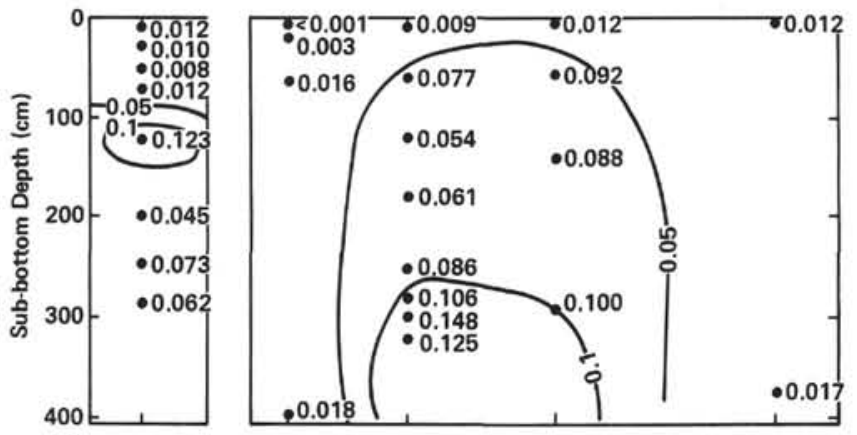

B

Figure 6. A. $\delta^{34} \mathrm{~S}(\%)$ of the sulfide sulfur values in the upper layer of sediments from the southeast Pacific (from Migdisov et al., 1978). B. Pyrite sulfur concentrations (\%). 